Article

\title{
Recovery and Reuse of Chromium Ions from Tannery Wastewater by Precipitation Reaction Method
}

\author{
Mohammed Tabidi
}

\begin{abstract}
The global concern about leather industries are increasing as leather industries grows bigger each year. These industries face very challenging task with an increase in stringent pollution control regulation enforced by various bodies due to environmental concern and human risks. The chromium salts are most widely used chemical for tanning process in leather industries, about $35 \%$ of chromium used for tanning process remain as metal and discharge to wastewater stream. The removal and recovery of this quantity of wasted chromium are necessary for environmental pollution control and economic reason. This paper shed light to chromium recovery and reuse system of Chromium salts in tanning wastewater by using $\mathrm{NaOH}$ as effective chemical precipitation method to regenerate chromium solution, adapted chrome recovery plant and evaluated the system technically and economically.
\end{abstract}

Keywords: Chromium; precipitation; tanning; leather industries; wastewater; sodium hydroxide

\section{INTRODUCTION:}

Leather industries is oldest fast growing industry as more and more different type of leather finished products needs increase that increase the growing of tanning industries in many countries. In order to improve the quality of leather, the leather cleaning and treatment process involving the following step like soaking, liming, deliming, pickling, vegetable tanning and chrome tanning industries. this processes of leather industries using high quantity of chemical like Sodium Chloride $\mathrm{NaCl}$ and Sodium Sulphate $\mathrm{Na}_{2} \mathrm{SO}_{4}$ and chromium and ammonium salt $\mathrm{NH}_{4} \mathrm{Cl}$ most of this chemical discharge into waste industrial effluent which made this industries one of the heavy pollution industries containing heavy metal like chromium, copper, nickel, lead, with high concentration exceeding the discharge limit which are not easy to remove by normal treatment chromium is common pollutant in tannery industries introduce to natural water from discharge of tannery effluent to wastewater.

Chromium is one of a heavy metal found in earth's crust, Chromium exists in two oxidation states (trivalent and hexavalent state) ${ }^{(1)}$ generally chromium found in trivalent state. The Chromium discharge to wastewater from tanning operation ${ }^{(1)}$. About 30 to $40 \%$ of chromium using for chrome tanning process discharge to wastewater hence its becomes necessary to remove of the chromium from wastewater due to environmental concerns and human risks ${ }^{(9)}$.

\section{MATERIALS AND METHODS}

Many specialized method and advanced treatment was used to remove the total chromium and hexavalent chromium from waste stream, e.g. ion exchange, membranes filtration, reverse osmosis, coagulation - flocculation, adsorption, electrocoagulation, flotation ${ }^{(10)}$,,combination of biological removal by using actinomycetes method (7) and the method of chemical precipitation Reactions (4) which becomes the most important method to remove of heavy metals, the literature showed that the percent of remove chromium from wastewater is $99 \%$ by using $\mathrm{MgO}$ which is more effective one among chemical precipitation method but $\mathrm{MgO}$ is too expensive to be economically. The precipitation reaction method of recovery and reuse of Chromium take place in the form of Chromium Hydroxide by using various agent like Magnesium Oxide, Calcium Oxide, Lime, Sodium Carbonate and Sodium 
Hydroxide etc. This paper shed light to present $\mathrm{NaOH}$ as superior chemical precipitation method used to recover and reuse chromium from wastewater ${ }^{(7)}$.

Sodium Hydroxide is attempted to be a promising alternative for overcoming a Precipitation reaction method for recovery and reuse of Chromium.

The Chromium recovered by added of Sodium Hydroxide as Chromium Hydroxide, the Chromium Hydroxide is dissolved by using Sulphuric acid the recovered Chromium uses as tanning liquor ${ }^{(4)}$. This method is more effective and cleaner solution which can not affect the quality of leather.

Daily pollution discharge details.

\begin{tabular}{|l|c|}
\hline parameters & total pollution load \\
\hline COD (Total) & $1500-2200$ \\
\hline COD $($ Soluble) & $1100-1500$ \\
\hline BOD(Total) & $630-930$ \\
\hline BOD(Soluble) & $440-670$ \\
\hline Total Solids & $5900-8500$ \\
\hline Dissolved Solids & $5200-7000$ \\
\hline Suspended Solids & $740-1500$ \\
\hline Chloride & $1550-2400$ \\
\hline Sulphide & $20-30$ \\
\hline Sulphate & $480-780$ \\
\hline Chromium & $20-30$ \\
\hline Phosphorus & $2-7$ \\
\hline Nitrogen & $110-190$ \\
\hline Dried Sludge & $1600-2500$ \\
\hline
\end{tabular}

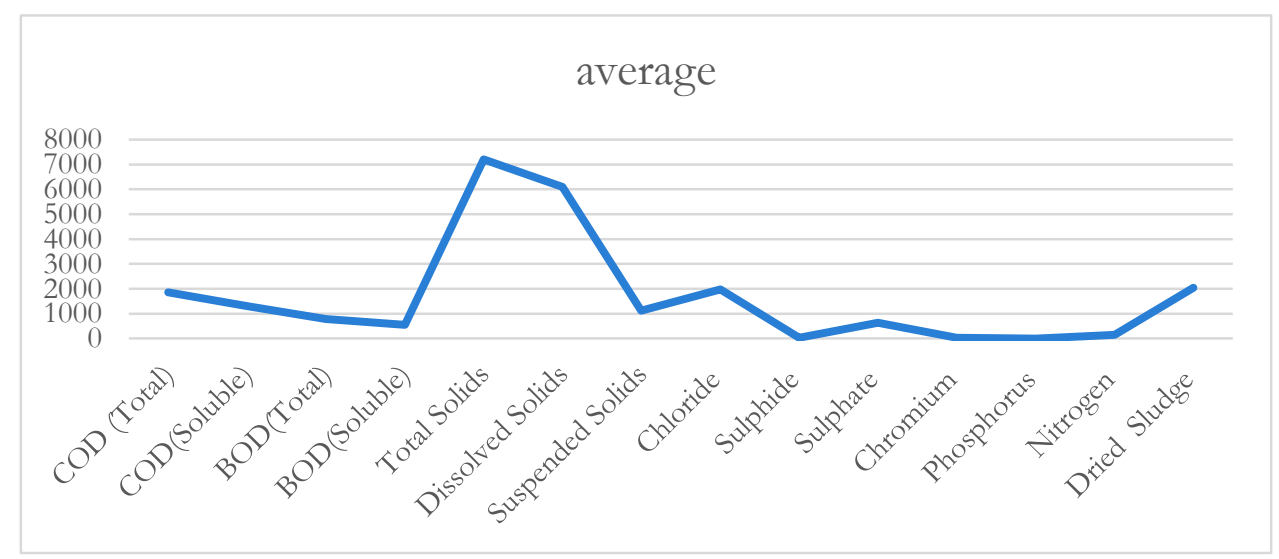

\section{Technology Adopted for Chrome Recovery and Reuse System}

The list of equipment installed into the chrome recovery plant are stainless steel Screens fixed before the collection tank pump, effluent collection equipped with reactor and stirrer, sodium hydroxide tank, with stirrer, chromium regeneration tank with mixer and dosing tank with dosing pump filled with Sulphuric acid and chromium liquor storage tank with Pump for regenerated chrome liquor. Figure 1-2 show process flow diagram for chrome recovery plant. 


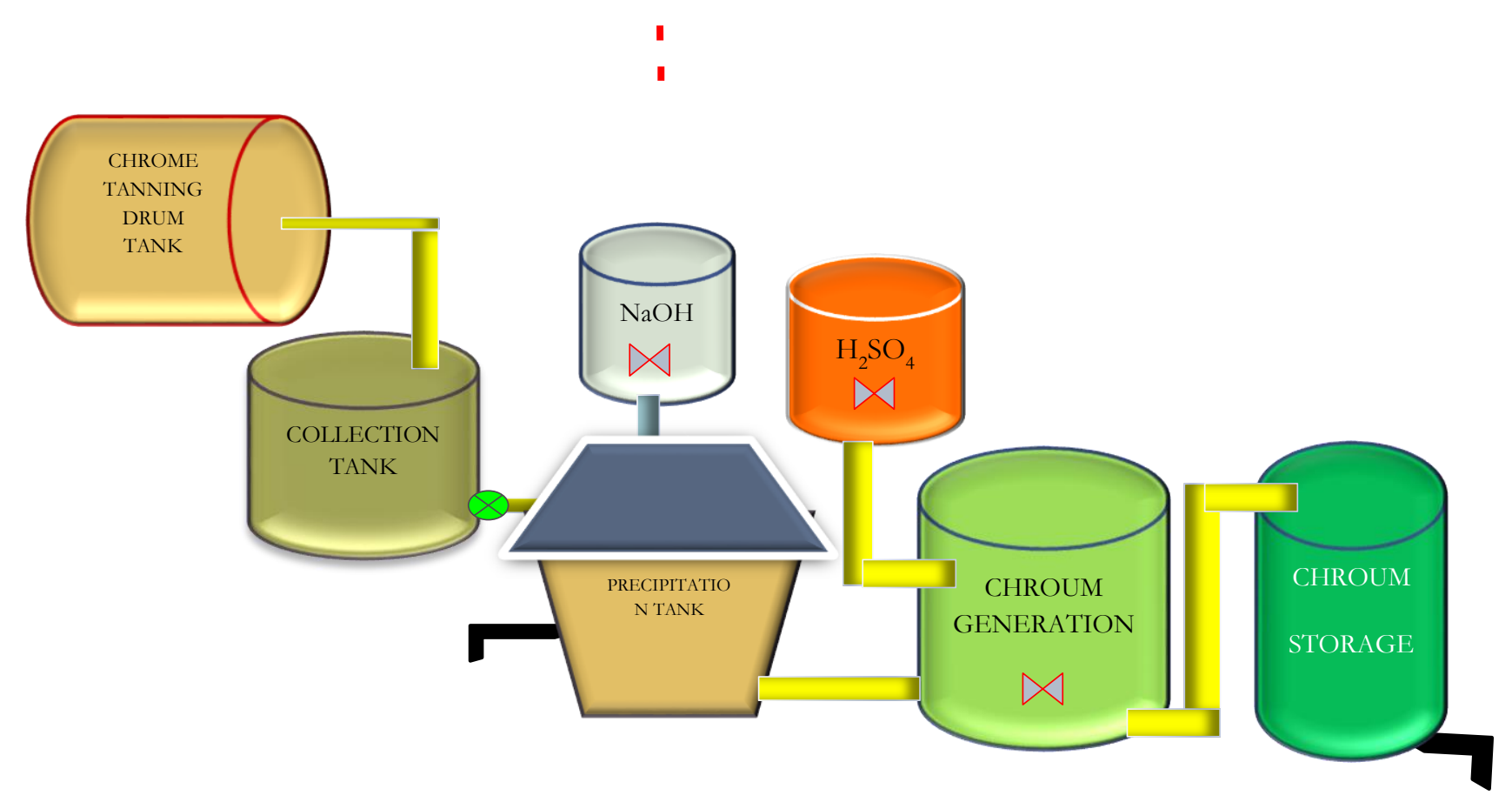

Figure 1-2. Process flow diagram for chrome recovery.

\section{Chrome Recovery Operation Procedures:}

The chrome tanning drums discharge solution into chromium drain channel, tanning solution will be filtered with stainless steel screen fixed at inlet point of chrome liquor's collection tank to remove large impurities, from this point the sample was collected and used for all the tests in this study like $\mathrm{Cr}^{+3}, \mathrm{Cr}^{+6}$, biological oxygen demand(BOD) chemical oxygen demand (COD) $\mathrm{pH}$, total solids, suspended solids (SS), etc. the spent tanning solution pumped by the submersible pump from collection tank into separation tank the solution then stirred with the mechanical mixer in separation tank the solution then basified to $\mathrm{pH}$ vale of 11 by addition of caustic soda and a known quantity of calcium carbonated added to the solution with continuous stirring for a period of one hour and stopped to allowed the liquor to settle for $5 \mathrm{hrs}$. The two layers of supernatant and precipitate layers are formed. The two layers will be separated. The precipitate layer which contained Chromium trivalent separated from the salt and transferred to Chromium regeneration tank and stirring by mechanical stirrer connected to Chromium regeneration tank during stirring the Sulphuric acid is added from Sulphuric acid dosing tank to acidified solution and adjust the $\mathrm{pH}$ range to 2-3 in regeneration tank, theoretically, $\mathrm{Cr}^{3+}$ removal depends in solution $\mathrm{pH}$ and temperature, the treated chromium is transferred to the chromium liquor storage tank.

\section{FUNDAMENTAL METHOD OF PRECIPITATION:}

\section{Chemical Precipitation:}

The chemistry of chromium is usually try to described clearly particularly on reaction of hexaaquachromium (III) ion $\left\{\mathrm{Cr}\left(\mathrm{H}_{2} \mathrm{O}\right)_{6}\right\}^{3}$ complex ions with ligands of water.

To achieve stabilization, the free hexaaquachromium (III) ion $\left\{\mathrm{Cr}\left(\mathrm{H}_{2} \mathrm{O}\right)_{6}\right\}^{3}$ Coordinated with anion containing free pairs electrons the stability depends on concentration of chromium metal and 
ligand, the number and orientation of and ligand of water as donor groups, the formed number and size of chelate ring and $\mathrm{PH}$ of solution ${ }^{(3)}$.

The reaction of free hexaaquachromium(III) ion $\left\{\mathrm{Cr}\left(\mathrm{H}_{2} \mathrm{O}\right)_{6}\right\}^{3}$ with sodium hydroxide $\mathrm{NaOH}$ removed hydrogen ions from water ligand in the hexaaquachromium(III) ion, the hydrogen removed from the three water molecules attached to hexaaquachromium(III) ion $\left\{\mathrm{Cr}\left(\mathrm{H}_{2} \mathrm{O}\right)_{6}\right\}^{3}$ the chromium complex become without charge (neutral complex) it will become insoluble in water and it precipitated in the solution.

\section{Hydroxide precipitation:}

Liquor solutions contain the violet, octahedral chromium (III) ion complex react with hydroxide to form precipitate of $\left\{\mathrm{Cr}(\mathrm{OH})_{3}\left(\mathrm{H}_{2} \mathrm{O}\right)_{3}\right\}_{(\mathrm{s})}$

\section{Reactions of hexaaquachromium ions with sodium hydroxide}

\section{Step-1 Adding hydroxide ions to 2+ hexaaquachromium ions}

$$
\begin{aligned}
& \left\{\mathrm{Cr}\left(\mathrm{H}_{2} \mathrm{O}\right)_{6}\right\}^{3+}(\mathrm{aq})+3 \mathrm{OH}^{-}(\mathrm{aq}) \longrightarrow\left\{\mathrm{Cr}(\mathrm{OH})_{3}\left(\mathrm{H}_{2} \mathrm{O}\right)_{3}\right\}_{(\mathrm{s})}+3 \mathrm{H}_{2} \mathrm{O}_{(\mathrm{l})} \\
& \text { Violet solution green solid }
\end{aligned}
$$

Adding hydroxide ion till new complex formed and this formed complex is neutral compound is insoluble in water and it is precipitated in the solution.

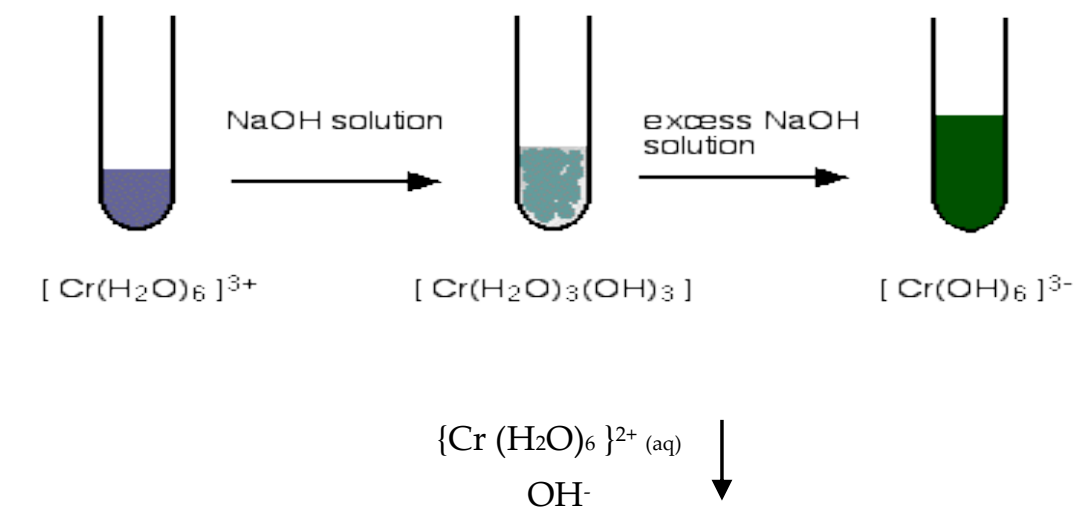

in each step one of proton remove from each complex (from $3^{+}$to 3

$$
\begin{gathered}
\left\{\mathrm{Cr}\left(\mathrm{H}_{2} \mathrm{O}\right)_{5} \mathrm{OH}^{-}\right\}^{+}{ }_{(\mathrm{aq})} \\
\mathrm{OH}^{-} \\
\left\{\mathrm{Cr}\left(\mathrm{H}_{2} \mathrm{O}\right)_{4}(\mathrm{OH})_{2}\right\}+(\mathrm{s})
\end{gathered}
$$

\{with addition of more hydroxide complex ions of (chromium (hydroxide III) ions) is neutralized and precipitated by ligand displacement OR replacement reactions as

$$
\left.\left[\mathrm{Cr}\left(\mathrm{H}_{2} \mathrm{O}\right)_{6}\right]^{3+}\right\}
$$

The formed precipitate of chromium hydroxide is written without including the water ligands as $\mathrm{Cr}(\mathrm{OH})$.

\section{Step - 2 Adding acid to hexahydroxochromate(III) ions}

Chromium(III) hydroxide[ $\left[\mathrm{Cr}(\mathrm{OH})_{6}\right]^{3-}$. known as an amphoteric hydroxide. Chromium(III) hydroxides because owned characteristic of amphoteric compound which may reacts with bases (hydroxide ions) to give $\left[\mathrm{Cr}(\mathrm{OH})_{6}\right]^{3-}$ and also when It reacts with acids like Sulphuric acid (hydrogen ions) to give $\left[\mathrm{Cr}\left(\mathrm{H}_{2} \mathrm{O}\right)_{6}\right]^{3+}$. When you add Sulphuric acid decreasing $\mathrm{pH}$ increasing $\mathrm{H}^{+} / \mathrm{H}_{3} \mathrm{O}^{+}$ concentration and protonating the chromium (III) complex. Because the hydrogen $\mathrm{H}+$ get put back. 

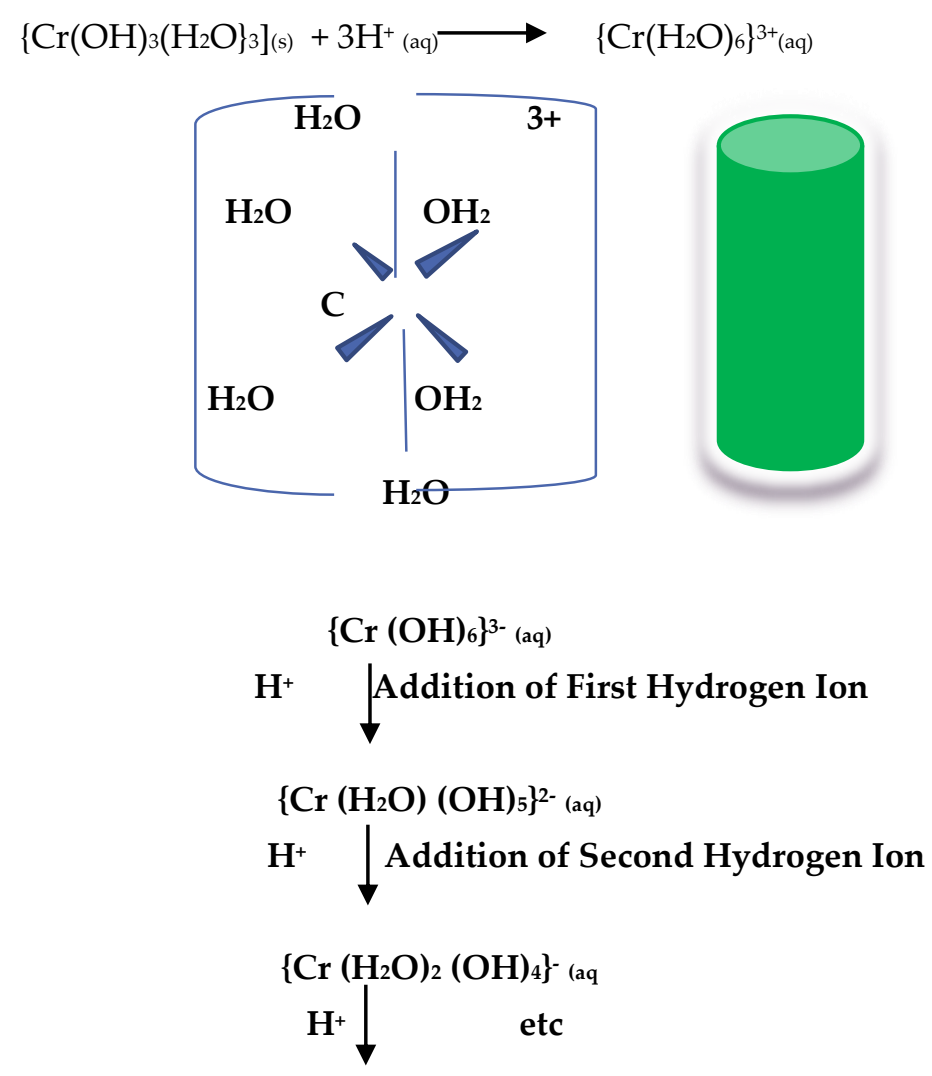

Neutral Complex formed (Precipitate appears)

$\left\{\mathrm{Cr}\left(\mathrm{H}_{2} \mathrm{O}\right)_{3}(\mathrm{OH})_{3}\right\}$ (s)

$\left\{\mathrm{Cr}\left(\mathrm{H}_{2} \mathrm{O}\right)_{4}(\mathrm{OH})_{2}\right\}^{+}$(aq)

$\left\{\mathrm{Cr}\left(\mathrm{H}_{2} \mathrm{O}\right)_{5}(\mathrm{OH})_{2}\right\}^{2+}$ (aq)

$\mathrm{H}^{+} \downarrow$ etc

$\left\{\mathrm{Cr}\left(\mathrm{H}_{2} \mathrm{O}\right)_{6}\right\}^{3+}$ (aq)

\{back to the original the precipitate dissolved completely\}

\section{RESULTS AND DISCUSSIONS:}

The characteristic of tanning wastewater

The tanning liquor was acidifying and treated wastewater contained concentrated $\mathrm{Cr}^{3+}, \mathrm{BOD}$, see table (1)

Measurements for the inlet streams of the treatment pilot plant and chromium recovery plant.

\begin{tabular}{|l|c|c|}
\hline \multicolumn{1}{|c|}{ Parameters } & Value & Average total pollution load kg/day \\
\hline $\mathrm{pH}$ & $9-7$ & - \\
\hline BOD & $1000-3000$ & 1600 \\
\hline
\end{tabular}




\begin{tabular}{|l|c|c|}
\hline COD & $2500-8000$ & 3400 \\
\hline Total solid & $15000-25000$ & 20500 \\
\hline Dissolved solid & $13000-21000$ & 17000 \\
\hline Suspended solid & $2000-4000$ & 2100 \\
\hline Chloride Cl- & $6000-9500$ & 4500 \\
\hline Sulphide & $30-50$ & 40 \\
\hline Sulphate & $1400-2000$ & 1700 \\
\hline Total chromium & $100-250$ & 130 \\
\hline
\end{tabular}

All value accept $\mathrm{pH}$ are in $\mathrm{mg} / \mathrm{L}$ source of the data $\mathrm{Al}$ Omania for tannery and leather industries. S. Oman

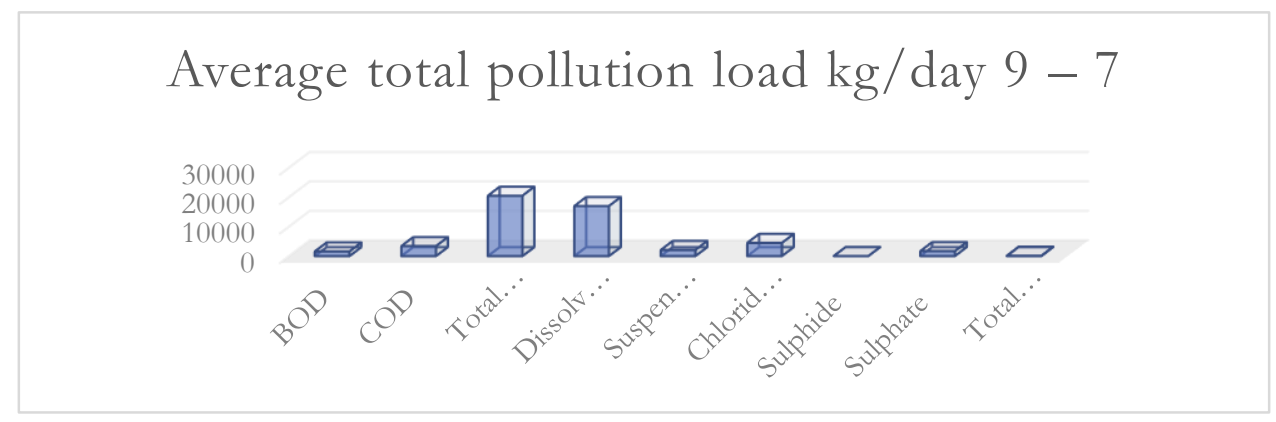

Emission factors for Chrome tanning in AL Omania for tannery and leather industries.

\begin{tabular}{cc}
\hline Parameter & Chrome tanning \\
\hline BOD & 1.5 \\
\hline COD & 2.2 \\
\hline Total solids & 70 \\
\hline Dissolved solids & 60 \\
\hline Suspended solids & 2.5 \\
\hline Chloride & 30 \\
\hline Total chromium & 3.8 \\
\hline
\end{tabular}

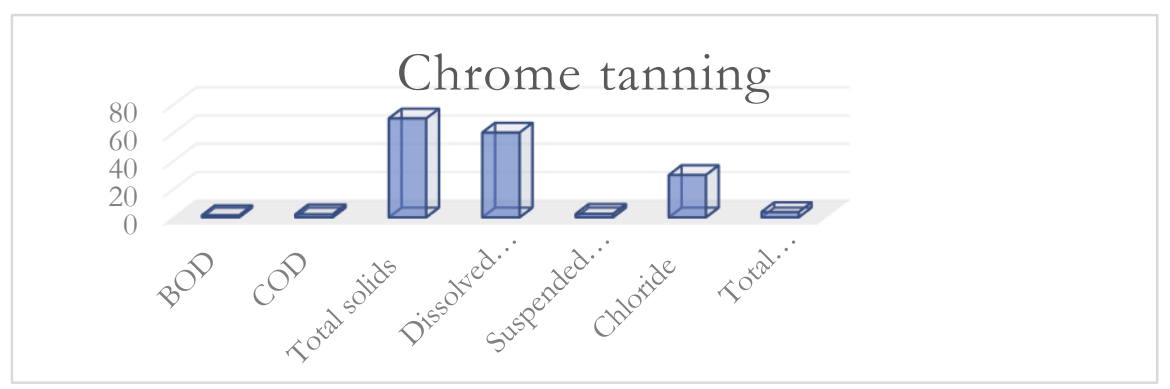

\section{Cost benefit analysis:}

The cost-benefit analysis is limited by the investment, performance, maintenance costs, and supply of chemicals. The recovery of chromium is profitable. Each year, the price of the new chromium salt increases, which brings additional benefits. According to Table 4, the total capital investment in the chromium recovery system is $\$ 52,000$ and the annual consumption of BCS is 240 tons per year. The waste is around 80 tons. The efficiency of the Chrome recovery system is greater than $99 \%$ We can collect $90 \%$ of the fluid from the Chrome exhaust host from Chrome Drum. Therefore, $70 \%$ of the chromium salts can be recycled and reused from a cost-benefit analysis, and you can see that the cost recovered from chromium, including all costs, is around 400US / T, while that the new chromium salt can cost more than $\$ 800 / \mathrm{t}$. The recovery period for the maintenance of the vineyard is less than three years. In addition to the direct economic benefits, the cost to operators, and the maintenance of waste management facilities is low. 


\begin{tabular}{cc}
\hline Total processing capacity & 3000tons \\
\hline Use of chromium salt (BCS) & 240tons/year \\
\hline Capital cost of the central chrome recovery system & 52,000US\$ \\
\hline Annual operating cost & Cost in US Dollars \\
\hline Maintenance & 1,500 \\
\hline Labor & 1,000 \\
\hline Chemicals & 9,000 \\
\hline Electricity & 500 \\
\hline Miscellaneous & 2,000 \\
\hline Total annual operating cost & 14,000 \\
\hline Financial cost & 7,800 \\
\hline Depreciation & 7,800 \\
\hline Total annual cost & 29,600 \\
\hline benefits & - \\
\hline Value of chromium recovery @ about US $\$ 800$ per ton for 70tons & $\$ 56,000$ \\
\hline Net profit / year & $\$ 26,000$ \\
\hline (UNIDO)Regional workshop on design, operation and maintenance of effluent treatment plants
\end{tabular}

(UNIDO)Regional workshop on design, operation and maintenance of effluent treatment plants 13 - 24 October 1997 - Chennai, India

\section{CONCLUSIONS:}

Recovery of chromium(III) salts discharge through spent tanning solution from tannery effluent by using chemical precipitation reaction to precipitate chromium as chromic hydroxide $\left(\mathrm{Cr}(\mathrm{HO})_{3} . \mathrm{nH}_{2} \mathrm{O}\right.$ or $\mathrm{Cr}(\mathrm{OH})_{3}$ or $\left.\mathrm{CrH}_{6} \mathrm{O}_{3}\right)$ is performed this design show the Effect of sodium hydroxide as best precipitant coagulant which give a voluminous chromium sludge and it is therefore separate the chromium sludge by decanted the supernatant liquor and chrome slurry is dissolved in Sulphuric acid and chromium Sulphate $\left\{\mathrm{Cr}_{2}\left(\mathrm{SO}_{4}\right)_{3}\right\}$ formed again as reusable liquor. The system is more than $99 \%$ efficient in recovery chrome from chrome tanning drum the level of chromium in wastewater reduce from $100-150 \mathrm{mg} / \mathrm{L}$ to $10-20 \mathrm{mg} / \mathrm{L}$ and it re-use water and this result in increasing financial benefit addition to prevent the disbursement of chromium pollution in environment.

\section{References:}

1. R.S. Karale, P.B. Nangare and D.V. Wadkar, "Removal and Recovery of Hexavalent Chromium from Industrial Wastewater by Precipitation with Due Consideration to Cost Optimization", Journal of Environmental Research and Develeopment, vol. 2(2), pp. 209-216, 2007

2. A. Esmaeili, A. Mesdaghi nia and R. Vazirinejad, “Chromium (III) Removal and Recovery from Tannery Wastewater by Precipitation Process", American Journal of Applied Sciences, vol. 2(10), pp. 1471-1473, 2005

3. Zheng Y, Bai D. Physio-chemical-biological treatment of tannery wastewater. Industrial Water and Wastewater 2001;32(5):52e4.

4. Baltpurvins, K.A., Burns, R.C., Lawrance, G.A., Stuart, A.D., 1997. Effect of electrolyte composition on zinc hydroxide precipitation by lime. Water Res. 31, 973-980.

5. Basu, M., Paul, A.K., 1999. Chromium resistant soil actinomycetes: their tolerance to other metals and antibiotics. Acta Microbiol. Immunol. Hungarica 46, 25-32

6. Basu, M., Paul, A.K., 1999. Chromium resistant soil actinomycetes: their tolerance to other metals and antibiotics. Acta Microbiol. Immunol. Hungarica 46, 25-32. 
7. Bopp LH., Ehrlich HL., 1988. Chromate resistance and reduction in Pseudomonas fluorescens strain LB300. Arch. Microbiol. 155: 4426-4431.

8. Panswad T, Techovanich A, Anotai J. A bench-scale study on chromium recovery from tanning wastewater. Water Sci Technol 1995;31(9):73e81. Khan, A.G., 2001.

9. Relationships between chromium biomagnififications ratio, accumulation factor, and mycorrhizae in plants growing on tannery efflfluent-polluted soil. Environ. Int. 26, 417-423.

10. Kurniawan, T.A., Chan, G.Y.S., Lo, W., Babel, S., 2006. Physico-chemical treatment techniques for wastewater laden with heavy metals. Chem. Eng. J. 118, 83-98

11. united nations industrial development organization regional programme for pollution control in the tanning industry in south east Asia

12. https://www.chemguide.co.uk/inorganic/complexions/aquaoh.html

13. Alguacil, F. J., et al. (2004). "Chromium (III) recovery from waste acid solution by ion exchange processing using Amberlite IR-120 resin: batch and continuous ion exchange modelling." Chemosphere 57(8): 789-793.

14. Avudainayagam, S., et al. (2003). "Chemistry of chromium in soils with emphasis on tannery waste sites." Rev Environ Contam Toxicol 178: 53-91.

15. $\{$ Alguacil, 2004 \#6;Avudainayagam, 2003 \#1;Avudainayagam, 2003 \#2;Kowalik-Klimczak, 2017 \#4;Liu, 2001 \#8;Pietrelli, 2004 \#7;Religa, 2015 \#5;Selvaraj, 2018 \#3\}

16. Avudainayagam, S., et al. (2003). "Chemistry of chromium in soils with emphasis on tannery waste sites." Rev Environ Contam Toxicol 178: 53-91.

17. Kowalik-Klimczak, A. and P. Gierycz (2017). "Scaling of nanofiltration membranes used for chromium(III) ions recovery from salt solutions." Water Sci Technol 76(11-12): 3135-3141.

18. Liu, M., et al. (2001). "Removal and recovery of chromium(III) from aqueous solutions by a spheroidal cellulose adsorbent." Water Environ Res 73(3): 322-328.

19. Pietrelli, L. and L. Xingrong (2004). "Chitosan membrane: tool for chromium (III) recovery from aqueous solutions." Ann Chim 94(5-6): 389-398.

20. Religa, P. and A. Kowalik-Klimczak (2015). "Effect of interaction between anionic surfactants and poly(piperazine-amide) nanofiltration membranes used for chromium(III) recovery from saline solution." Water Sci Technol 72(10): 1803-1809.

21. Selvaraj, R., et al. (2018). "A membrane electroflotation process for recovery of recyclable chromium(III) from tannery spent liquor effluent." J Hazard Mater 346: 133-139.

22. Dargo H., Ayalew A., Tannery Waste Water Treatment: A Review, Int. J. Emerg. Tren. Sci. \& Tech., 2014; 1 (9): 1488-1494,

23. Removal of heavy metal ions from wastewaters: A review Fenglian Fu a, *, Qi Wang b a Faculty of Environmental Science and Engineering, Guangdong University of Technology, Guangzhou 510006, PR China b Faculty of Applied Mathematics, Guangdong University of Technology, Guangzhou 510006, PR China

24. Berners-Lee M. How Bad are Bananas? : The Carbon Footprint of Everything, Profile Books LTD, London. 2010.

25. Multilateral Investment Guarantee Agency. Environmental Guidelines for Tanning and Leather Finishing, P.499- 503. [https://www.miga.org/documents/Tanning and Leather Finishing.pdf (accessed on November 10, 2017)] 